\title{
DEHIDRATASI VIRGIN COCONUT OIL DENGAN SODA ASH UNTUK MEMENUHI STANDAR NASIONAL INDONESIA PADA KELOMPOK TANI BINA WARGA 1 DESA PANCANEGARA KECAMATAN PABUARAN KABUPATEN SERANG
}

\author{
Sri Sulasminingsih ${ }^{1}$, Budiman Adi Setyawan ${ }^{2}$, Lomo Mula Tua ${ }^{3}$ \\ Prodi Teknik Industri, Universitas Pembangunan Nasional "Veteran” Jakarta, Jakarta Selatan, Indonesia ${ }^{1}$ \\ Prodi Teknik Perkapalan, Universitas Pembangunan Nasional "Veteran” Jakarta, Jakarta Selatan, Indonesia ${ }^{2}$ \\ Prodi Manajemen Informatika, Univ. Pembangunan Nasional “Veteran” Jakarta, Jakarta Selatan, Indonesia ${ }^{3}$ \\ email $^{1}$ : srisulasminingsih125@gmail.com
}

\begin{abstract}
The identification of Virgin Coconut Oils (VCO) components had been done from Kelompok Tani Bina Warga 1 Desa Pancanegara productions.The identifications had been done especially to isolated method with natrium carbonate added, that is called with the dehydrated proses.VCO analysis of physical properties like density and organoleptic test, standard of benefit value correlation with composition of essensial fatty acids and standard of endurance levels like water and free fatty acids content. The Result of this identifications that inducement isolation methode provided 0,130 litre $/ \mathrm{kg}$ of VCO, colourless, deliciously and fragrant cocont oily, density 0,925 $(\mathrm{g} / \mathrm{ml})$, water content $0,19 \%$, free fatty acids 0,10\%. Fatty acids composition those are lauric 39,0 \% (45,1-53,2 $\%)$, myristic $17,8 \%(16,8-21 \%)$, palmitic $8,7 \%(5,0-10,0 \%)$. The result of this identification appropriate with SNI 7381:2008 and Asian and Pacific Coconut Community (APCC) are still below.
\end{abstract}

Keywords: VCO (Virgin Coconut Oil), organoleptic test, lauric acid.

\section{PENDAHULUAN}

Desa Pancanegara termasuk salah satu desa yang berada di wilayah Kecamatan Pabuaran Kabupaten Serang, Provinsi Banten. Berada pada ketinggian 450 meter diatas permukaan laut dengan luas wilayah $5,45 \mathrm{~km}^{2}$. Desa ini berada di dataran dengan kemiringan lahan sedang $\left(15-25^{\circ}\right)$. Desa Pancanegara terdiri dari 24 RT dan 9 RW dengan jumlah penduduk 5.492 jiwa yang terdiri dari 2.828 laki-laki dan 2.664 perempuan atau $13,97 \%$ dari seluruh populasi penduduk di Kecamatan Pabuaran. Desa Pancanegara memiliki potensi perkebunaan kelapa rakyat yang luas. Selama ini buah kelapa (tua) diolah menjadi minyak kelapa dan buah kelapa yang muda dijual untuk dijajakan di warung-warung sebagai minuman kelapa muda.Namun demikian ada sekelompok orang yang kreatif yang bergabung ke dalam perkumpulan Kelompok Tani Bina Warga 1 melakukan terobosan berupa pengolahan kelapa menjadi produk lain yaitu menjadikan minyak kelapa murni (VCO) . VCO dibuat dari buah kelapa tua yang diambil santannya. Santan diaduk secara merata lalu didiamkan selama 36 jam sampai terbentuk dua lapisan. Minyak berada di lapisan atas dan air/protein di bawah . Akhirnya minyak (VCO) dapat diambil dengan cara disendok, ditampung di dalam ember besar dan dikemas ke dalam botol-botol kecil lalu dijual. Produk ini memiliki nilai ekonomi yang tinggi karena bermanfaat untuk kesehatan dan perawatan kecantikan, antimikroba, sistem kekebalan tubuh, antibiotika super,menjaga kesehatan jantung dan pembuluh darah,osteoporosis,diabetis mellitus dll. VCO mengandung $92 \%$ asam lemak rantai sedang dengan kandungan terbesarnya adalah asam laurat (45-55\%). Asam laurat dapat terserap langsung melalui dinding usus (tanpa proses hidrolisis dan enzimatik) terus masuk ke dalam aliran darah dan dibawa masuk ke dalam hati untuk dimetabolisir. VCO diproses menjadi energi (bukan kolesterol) yang akan digunakan untuk meningkatkan fungsi semua kelenjar endokrin, organ dan jaringan tubuh. Produk ini akan diangkat menjadi suatu bisnis kreatif inovatif dengan mengembangkan jiwa kewirausahaan dari Kelompok Tani Bina Warga1 Desa Pancanegara Kecamatan Pabuaran.Untuk menjaga mutunya perlu dilakukan analisis terhadap minyak kelapa murni (VCO) produk 
Kelompok Tani Bina Warga 1 sebagai langkah lanjut pembangunan masyarakat Desa Pencanegara melalui program strategis penelitian dan pemberdayaan masyarakat di bidang produksi dan pemasaran minyak kelapa murni.

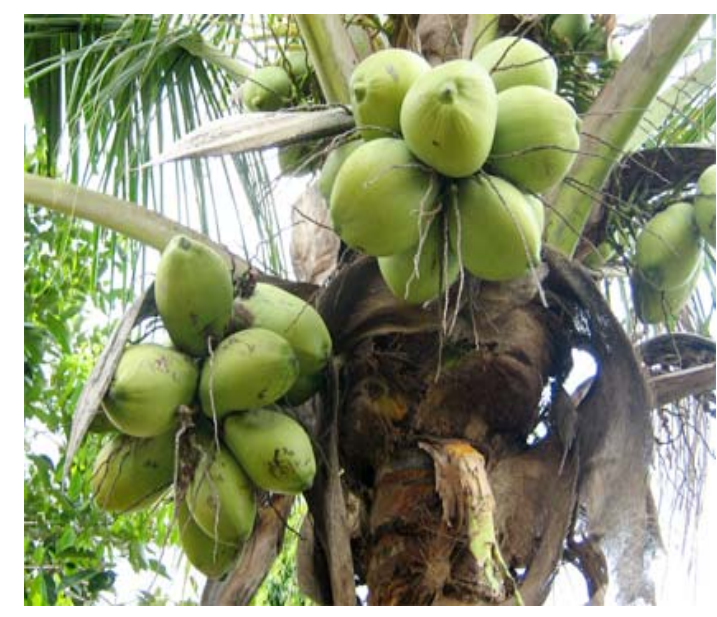

Gambar 1. Kelapa (Cocos nucifera) marga Cocos atau Arecaceae

\section{PERUMUSAN MASALAH}

Sampai saat ini belum pernah ada riset tentang kualitas maupun pemasaran terhadap produk minyak kelapa murni dari Kelompok Tani Bina Warga 1 Desa Pancanegara. Apalagi sertifikat hasil uji kualitas yang resmi dikeluarkan oleh instansi terkait sehingga standar mutu produknya belum dapat dipublikasikan . Untuk mendapatkan kepercayaan dari masyarakat hal itu harus dilakukan - Apalagi jika ingin pemasarannya maju dan berkembang bahkan sampai di ekspor ke mancanegara. Cara pembuatan minyak kelapa murni tanpa pemanasan dengan waktu pendiaman selama 36 jam masih mempunyai kelemahan sehingga produk perlu diuji kembali melalui penelitian yang sesuai dengan standar (SNI). Dibutuhkan waktu pendiaman yang lebih lama ( > 36 jam) agar kadar airnya berkurang. Hal tersebut merupakan masalah yang harus diatasi oleh Kelompok Tani Bina Warga 1 Desa Pancanegara . Untuk itu dilakukan suatu percobaan untuk mempercepat prroses pemisahan air dari dalam minyak kelapa dengan cara menambahkan soda ash ke dalamnya . Permasalahan yang terjadi dapat dirumuskan menjadi :

1.Apakah minyak kelapa murni produk Kelompok

Tani Bina Warga 1 Desa Pancanegara dapat dipisahkan airnya lebih cepat dengan memakai soda ash ?

2.Apakah dapat memenuhi standar SNI 7381-2008 ?

\section{TUJUAN PENELITIAN}

Penelitian ini bertujuan untuk mempercepat waktu pembuatan minyak kelapa murni dengan cara penarikan air denngan menggunakan natrium karbonat dibandingkan cara gravitasi yang lebih lama sehingga dihasilkan kadar air di dalam minyak yang seminimal mungkin.

\section{TINJAUAN PUSTAKA}

Teknik pembuatan minyak kelapa terbagi dua yaitu RDB (Refined,Bleached and Deodorized) adalah minyak kelapa yang dibuat dengan cara pemurnian, pengelantangan dan penghilangan bau dan VCO (Virgin Coconut Oil/minyak kelapa murni) adalah minyak kelapa murni dan segar yang diolah melalui pembuatan santan dengan cara sentrifus atau pemanasan bertahap.Berdasarkan penelitian terdahulu yang dilakukan oleh Muhammad Asy’ari \& Bambang Cahyono bahwa VCO yang dibuat dengan cara pemancingan selama 10-12 jam menghasilkan minyak sebanyak 0,150 liter per kilogram yang relatip tidak berbeda dengan cara-cara yang lainnya.Hasil pengujian organoleptik/ Fisika menunjukkan warna yang jernih, rasa yang gurih dan bau yang wangi serta berat jenis $\mathbf{0 , 9 2 4}$. Pengujian terhadap keawetan minyak VCO memberikan data sebagai berikut :

1. Kadar Air $0,00 \%$,

2. Kadar Nitrogen $0,0000 \%$ dan

3. Kadar Peroksida Positip (+) serta

4. Kadar Asam lemak bebas $0,002 \%$.

5. Hasil Pengujian Kimia GC-MS seperti pada tabel 1.

\section{Soda Ash atau Soda Abu}

Soda ash atau soda abu dikenal juga sebagai soda cuci dengan rumus kimia $\mathrm{Na}_{2} \mathrm{CO}_{3}$ atau natrium karbonat merupakan garam natrium dari asam karbonat. Sifat-sifatnya antara lain mudah larut dalam air,berbentuk bubuk berwarna putih,mampu menyerap embun/uap air dari udara dan mempunyai rasa alkali atau pahit serta membentuk larutan alkali yang kuat. Di dalam industri kaca , soda ash dipakai untuk membentuk fluks dengan silika sehingga terbentuk kaca soda kapur yaitu salah satu jenis kaca. Soda ash juga digunakan untuk menetralkan efek korosi dari klorin pada kolam renang dengan cara menaikkan $\mathrm{pH}$ air kolam.Di dalam produk-produk kimia soda ash digunakan sebagai elektrolit . Pada penggunaan di dalam rumah tangga, soda ash dipakai sebagai pelembut air untuk mencuci pakaian dan mencegah terjadinya reaksi antara ion-ion magnesium atau kalsium dengan deterjen yang sedang dipakai serta dapat menghilangkan 
kotoran yang berupa minyak,oli serta karat anggur.

Tabel 1. Komposisi Asam Lemak yang terkandung dalam VCO

\begin{tabular}{|l|l|l|l|l|}
\hline NAMA & JENIS & $\begin{array}{l}\text { KADAR } \\
\%\end{array}$ & $\begin{array}{l}\text { SNI } \\
7381 \\
:\end{array}$ & $\begin{array}{l}\text { APCC } \\
(\%)\end{array}$ \\
\hline $\begin{array}{l}\text { Asam } \\
\text { Laurat }\end{array}$ & MCFA & $\mathbf{3 9 , 6 9}$ & $\begin{array}{l}45,1- \\
53,2\end{array}$ & $43-53$ \\
\hline $\begin{array}{l}\text { Asam } \\
\text { Miristat }\end{array}$ & MCFA & 24,12 & $\begin{array}{l}16.8- \\
21\end{array}$ & $16-21$ \\
\hline $\begin{array}{l}\text { Asam } \\
\text { Palmitat }\end{array}$ & LCFA & 11,17 & $\begin{array}{l}7,5- \\
10,2\end{array}$ & $\begin{array}{l}7,5- \\
10\end{array}$ \\
\hline $\begin{array}{l}\text { Asam } \\
\text { Kaprat }\end{array}$ & MCFA & 7,27 & $\begin{array}{l}5,0- \\
8,0\end{array}$ & $4,5-8$ \\
\hline $\begin{array}{l}\text { Asam } \\
\text { Oktanoat }\end{array}$ & MCFA & 6,94 & $\begin{array}{l}4,6- \\
10\end{array}$ & $5-10$ \\
\hline $\begin{array}{l}\text { Asam } \\
\text { Oleat }\end{array}$ & UFA & 6,48 & $\begin{array}{l}5,0- \\
10,0\end{array}$ & $4-10$ \\
\hline Asam & LCFA & 3,03 & $2,0-$ & $2-4$ \\
\hline Linoleat & UFA & 0,79 & $1,0-$ & $1-2,5$ \\
\hline & & & 0,7 & 0,6 \\
\hline
\end{tabular}

Pada proses pengujian, soda ash digunakan untuk mengidentifikasi adanya logam lain membentuk endapan yang berwarna tergantung pada logam apa dia bersenyawa. Di dalam industri makanan dan kesehatan, soda ash digunakan sebagai pengatur keasaman, pengembang, penstabil dan zat anti lengket pada kue, roti dan mie Cina. Pada produk hasil industri, soda ash terdapat pada pasta gigi sebagai pembentuk busa dan abrasi serta berfungsi untuk menaikkan $\mathrm{pH}$ mulut. Soda ash dapat diekstrak dari abu-abu tanaman yang tumbuh di tanah yang kaya natrium, dapat disintesis dari garam natrium klorida dan batu kapur dengan metoda Solvay dan dapat dibuat dengan memanaskan natrium bikarbonat yang menghasilkan air dan karbon dioksida.

$$
2 \mathrm{NaHCO}_{3} \longrightarrow \mathrm{Na}_{2} \mathrm{CO}_{3}+\mathrm{H}_{2} \mathrm{O}+\mathrm{CO}_{2}
$$

\section{Dehidratasi.}

Air merupakan salah satu komponen yang menentukan kualitas minyak kelapa murni (VCO). Adanya air di dalam minyak kelapa murni akan menentukan kualitas kemurnian selain kandungan asam lemak tertentu yang tinggi. Oleh sebab itu kadar air di dalam minyak kelapa murni (VCO) harus seminimal mungkin agar mutunya tinggi. Ada banyak cara agar supaya kandungan air di dalam minyak kelapa murni menjadi sangat kecil. Cara yang paling mudah, murah dan aman adalah dengan mendiamkannya dalam waktu yang cukup lama sehingga air terpisah dari minyak. Minyak berada di lapisan atas dan air berada pada lapisan bawah. Karena berat jenis minyak lebih kecil dari pada air maka minyak akan berada diatas dan sebaliknya. Cara ini mendekati sempurna hanya membutuhkan waktu yang lama sehingga bagi para pengusaha hal ini menjadi hambatan di dalam mengejar target produksi yang maksimal. Cara yang lain diantaranya dengan menambahkan zat kimia tertentu yang yang mempunyai sifat tidak suka akan minyak (liofob) sehingga tidak dapat bereaksi dengan minyak. Beberapa zat kimia yang bersifat hidrofil dapat dimasukkan kedalam campuran minyak dalam air dengan maksud agar terjadi penarikan air dari dalam minyak kelapa murni. Dehidratasi merupakan suatu proses menarik air dari dalam larutan. Air yang tersuspensi di dalam minyak membutuhkan waktu yang lama agar dapat terpisah jika hanya mengandalkan pada gravitasi. Untuk mempercepat pemisahan air dari dalam minyak maka dicoba suatu cara dengan menambahkan soda ash ke dalam larutan minyak dalam air. Soda ash akan membantu mempercepat terjadinya proses pemisahan air dari minyak sehingga waktu yang digunakan akan lebih singkat. Sifat soda ash yang hidrofil akan menarik seluruh air dari dalam minyak sehingga menjadi bebas air. semakin kecil kandungan air di dalam minyak kelapa murni semakin lama daya tahan atau keawetannya dalam penyimpanan.

\section{METODA PENELITIAN}

Metoda penelitian yang digunakan adalah metoda eksperimental yang terdiri dari empat tahap penting. Tahap pertama adalah survai/studi kepustakaan untuk mendapatkan informasi awal. Tahap kedua adalah pengumpulan bahan. Tahap yang ketiga adalah proses pembuatan minyak kelapa murni (VCO). Tahap ke empat adalah analisis terhadap produk 
minyak kelapa murni dengan cara pengujian Uji Asam Lemak Bebas (SNI 7381:2008 Lampiran B.5), Uji Bau (SNI 7381:2008 Lampiran B.2.1) dan Uji Kadar Air (SNI 7381:2008 Lampiran B.3)

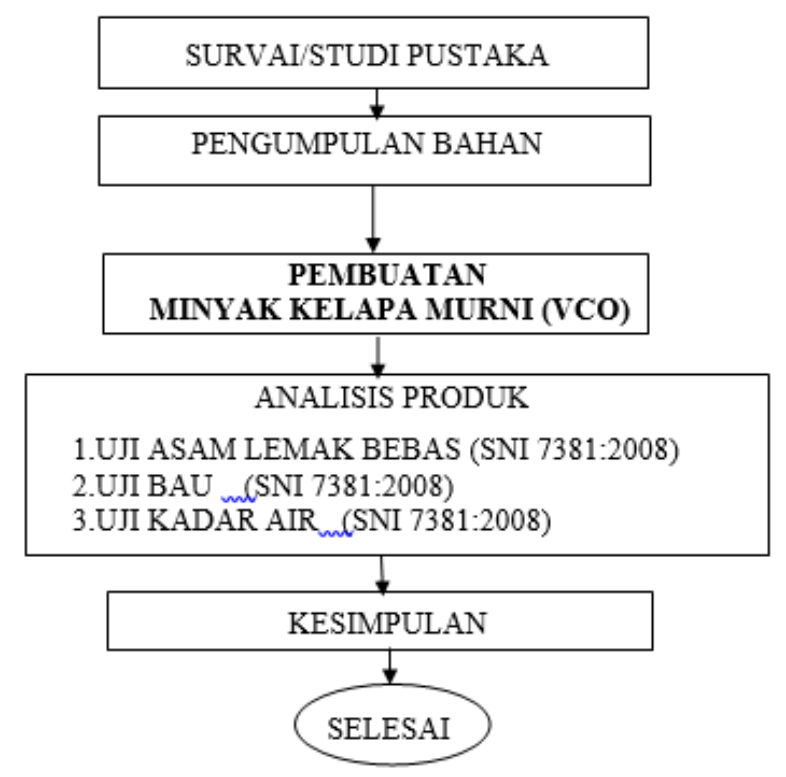

Gambar 1 Diagram Alir Penelitian

\section{Survai Pustaka}

Studi kepustakaan dilakukan untuk mengetahui secara teoritis bagaimana cara membuat minyak kelapa murni dengan baik dan benar sesuai dengan panduan nasional, regional maupun internasional. Banyak perpustakaan telah dikunjungi untuk mencari informasi yang dibutuhkan antara lain LIPI, IPB dan Kementerian Pertanian. Tidak lupa pula penelusuran melalui internet yang banyak sekali manfaatnya sebagai refensi yang mendukung. Ada banyak teori yang menerangkan tentang cara-cara pembuatan minyak kelapa murni (VCO) ini yang secara umum terbagi ke dalam dua bagian besar.

\section{Pengumpulan Bahan}

Bahan baku minyak kelapa murni (VCO) diperoleh dari perkebunan kelapa rakyat di sekitar Desa Pancanegara Kecamatan Pabuaran Kabupaten Serang . Akibat dari musim hujan yang terus menerus tiada henti maka panen kelapa dipercepat karena dikhawatirkan kadar air di dalam kelapa menjadi tinggi sehingga akan mempengaruhi kandungan senyawa kimia lain di dalamnya. Pada saat panen kelapa, buah kelapa hasil panen diseleksi hanya yang tua saja yang diambil untuk mendapatkan mutu minyak kelapa murni yang baik sesuai standar yang berlaku.

\section{Pembuatan Minyak Kelapa Murni (VCO)}

Kelapa tua yang telah dipilih untuk dijadikan minyak kelapa murni(VCO) diambil dagingnya lalu diparut. Kemudian tambahkan air hangat secukupnya ke dalam kelapa parut agar memudahkan proses pengeluaran santannya. Santan yang diperoleh ditempatkan pada wadah (platik besar) yang bersih, steril dan transfaran. Lalu tambahkan larutan natrium karbonat $1 \%$ ke dalam santan, aduk perlahan lahan sampai campurannya merata dan diamkan selama 3 jam dalam kondisi wadah tertutup dan di tempat yang kering sampai terbentuk krim santan. Pisahkan krim santan dari pelarut airnya dan tempatkan krim santan pada wadah lain yang bersih, steril, transfaran dan bertutup. Lalu pisahkan minyak VCO dari krim santan dengan cara penyaringan menggunakan kertas saring yang bersih dan steril (Whatmann 20). Pembuatan dengan metoda ini ssama seperti cara membuat minyak kelapa bukan VCO.

\section{Analisis Kualitas Fisik VCO.}

Kualitas fisik minyak kelapa murni (VCO) dianalisis berdasarkan SNI 7381:2008. Analisis sifat fisik meliputi analisis warna, rasa dan bau dilakukan dengan metoda organoleptik yaitu cara analisis dengan menggunakan pancaindera. Indera penglihatan (mata) untuk mengamati perubahan warna VCO, indera pengecap (lidah) untuk merasakan perubahan rasa dan indera penciuman (hidung) untuk mencium adanya perubahan aroma (bau) dari VCO. Cara pengujian tersebut berdasarkan Standar SNI 7381:2008 dengan kriteria sebagai berikut:

1. Bau - khas kelapa segar , tidak tengik

2. Rasa-Normal,khas minyak kelapa

3. Warna-Tidak berwarna/jernih hingga kuning pucat

Sedangkan penentuan berat jenisnya dilakukan dengan cara piknometri (alat Piknometer). Standar Berat Jenis VCO menurut APCC sebesar 0,915$\mathbf{0 , 9 2 0 .}$

\section{Analisis Standar khasiat VCO.}

Dalam skala regional ada organisasi yang mengatur tentang standar khasiat minyak kelapa murni (VCO) yaitu APCC (Asian and Pacific Coconut Community). Berdasarkan ketentuan/standar APCC bahwa khasiat VCO tergantung pada komposisi asam-asam lemaknya. Terutama ditentukan oleh kadar asam laurat yang merupakan komponen terbesar di dalam VCO. Semakin tinggi kadar asam laurat maka kualitas VCO semakin baik. Kadar asam laurat yang baik adalah 45,1-53,2\% (SNI 7381:2008) atau 45-56\% (APCC). Tinggi rendahnya kadar asam laurat tergantung pada tua atau mudanya buah kelapa. 
Semakin tua buah kelapa akan semakin tinggi kandungan asam lauratnya demikian pula sebaliknya. Penentuan komposisi asam-asam lemak dilakukan dengan memakai cara gabungan Gas Chromatography-Mass Spectroscopy (GC-MS).

\section{Analisis Standar Keawetan VCO.}

Keawetan adalah berapa lamanya waktu yang dibutuhkan oleh minyak kelapa murni untuk tetap bertahan tidak berubah dalam kondisi yang baik sampai menjadi rusak. Beberapa paramerter yang berkaitan dengan kerusakan VCO adalah karena adanya unsur peroksida, asam lemak bebas, nitrogen dan air di dalam VCO. Semua unsur yang dapat menyebabkan kerusakan itu harus ditekan sekecil mungkin agar diperoleh VCO yang memenuhi standar atau berkualitas baik. Untuk menentukan adanya peroksida di dalam VCO dilakukan dengan uji kualitatif peroksida. Penentuan kadar nitrogen dilakukan dengan menggunakan cara titrasi formol. Penentuan kadar asam lemak bebas (FFA) dilakukan dengan titrimetri dan penentuan kadar air dilakukan berdasarkan standar SNI 01-3751-2000, ICS 67.060)

\section{HASIL DAN PEMBAHASAN Pembuatan VCO}

Buah kelapa lokal yang telah tua hasil pemetikan dikupas dan diambil dagingnya sebanyak 8 kg. kemudian dicuci dan diparut. Selanjutnya tambahkan air hangat secukupnya (30 liter) untuk memudahkan proses pemerasan santannya. Kelapa yang telah diparut lalu diperas. Santan yang diperoleh ditempatkan pada wadah platik besar yang bersih, steril dan transfaran. Lalu didiamkan selama 3 jam sampai terbentuk krim santan. Pisahkan krim santan dari pelarut airnya dan tempatkan krim santan pada wadah lain yang bersih, steril, transfaran dan bertutup. Kemudian tambahkan soda ash 5\% sebagai pemancing agar terjadi pemisahan air dengan cepat. Aduk perlahan-lahan sampai campurannya merata lalu didiamkan selama 3 jam dalam kondisi wadah tertutup dan di tempat yang kering. Kemudian pisahkan minyak VCO dari krim santan dengan cara penyaringan menggunakan kertas saring yang bersih dan steril (Whatmann 20)

Hasil produksi minyak VCO Kelompok Tani Bina Warga 1 Desa Pancanegara, Kecamatan Pabuaran Kabupaten Serang Provinsi Banten dengan cara pemancingan sebanyak $\mathbf{0 , 1 3 0 ~ l i t e r / k g}$ daging kelapa merupakan hasil yang normal karena apabila dibandingkan dengan penelitian-penelitian lainnya menunjukkan tidak ada perbedaan yang signifikan. Waktu pendiaman yang relatif lebih lama sampai 3 jam ternyata telah memberikan waktu yang cukup bagi minyak VCO untuk terpisah dari krim santannya. Cara pemancingan merupakan cara pembuatan VCO yang paling baik jika dibandingkan dengan beberapa cara yang lain karena akan didapat VCO yang benar-benar murni secara kimia. Tidak ada komponen yang rusak atau terdegradasi akibat dari proses pembuatan VCO yang dipaksakan seperti pemanasan, pemberian katalis dsb.

\section{Analisis kualitas fisik VCO}

Hasil uji organileptik berdasarkan standar SNI 7381: 2008 terhadap VCO produk Kelompok Tani Bina Warga 1 Desa Pancanegara yang dibuat dengan metoda pemancingan menunjukkan kualitas yang baik. Hal itu ditunjukkan dengan hasil uji warna yang masih tetap jernih, uji rasa yang masih tetap gurih dan hasil uji bau yang masih tetap wangi khas kelapa segar, tidak tengik. Metoda pemancingan dalam pembuatan VCO tidak menjadikan protein dalam krim santan terdegradasi yang dapat menyebabkan kualitas VCO menurun. Cara pemanasan akan menyebabkan pigmen-pigmen dari buah kelapa menjadi larut dan terdegradasi atau berubah struktur molekulnya sehingga berubah warna menjadi kuning dan tidak jernih lagi.

Hasil pengukuran berat jenis (bj) VCO yang dibuat dengan cara pemancingan dari Kelompok Tani Bina Warga 1 Desa Pancanegara Kecamatan Pabuaran menunjukkan angka 0,925 (g/ml).Angka tersebut masih diatas standar dari APCC Asian and Pacific Coconut Community) sebesar 0,915-0,920 (g/ml).Berat Jenis VCO produksi Kelompok Tani Bina Warga 1 Desa Pancanegara Kecamatan Pabuaran sedikit lebih tinggi dari standar APCC .Berat jenis yang lebih besar menunjukkan masih adanya air di dalam VCO sehingga kadar kemurniannya menjadi lebih rendah dan berarti kualitasnya lebih rendah dari standar APCC . Cara pengukuran berat jenis VCO adalah dengan menimbang VCO sebanyak $1 \mathrm{ml}$ pada timbangan analitis. Beratnya dicatat dan dilakukan berulang sampai lima kali kemudian dirata-ratakan. Semakin ringan timbangan VCO berarti semakin tak mengandung air dan semakin berat VCO (mendekati $1 \mathrm{~g} / \mathrm{ml}$ ) berarti masih terdapat air di dalamnya.

\section{Analisis Standar Khasiat VCO.}

Hasil Analisis GC-MS VCO produk Kelompok Tani Bina Warga 1 Desa Pancanegara, Kecamatan Pabuaran menunjukkkan ada 3 jenis asam lemak dalam jumlah terbesar yang terkandung di dalam VCO (Tabel 2). Kandungan asam lemak tertinggi adalah asam laurat sebesar $\mathbf{3 9 , 0} \%$ yang masih dibawah standar SNI 7381:2008. Ambang batas yang direkomendasikan oleh SNI adalah 45,1-53,2 $\%$ dan APCC pada 43,0-53,0 \%. Kadar asam laurat masih dibawah standar karena bahan baku kelapa yang diperoleh dari pengepul tidak seragam keadaan dan sumbernya.

Kandungan asam lemak jenuh terutama yang punya rantai pendek (Short Chain Fatty Acid/ SCFA) 
sampai rantai sedang (Middle Chain Fatty Acid/MCFA) ditengarai akan meningkatkan kualitas dari VCO. Hal ini berkaitan dengan semakin mudahnya jenis asam lemak tersebut untuk ditranspor di dalam darah dan akan segera diubah menjadi energi setelah masuk ke dalam sel.

Tabel 2. Komposisi asam lemak yang terdapat di dalam VCO produk Kelompok Tani Bina Warga 1 Desa Pancanegara

\begin{tabular}{|l|c|c|c|c|}
\hline NAMA & JENIS & $\begin{array}{c}\text { KADAR } \\
\text { (\%) }\end{array}$ & $\begin{array}{c}\text { STANDAR } \\
\text { SNI }\end{array}$ & $\begin{array}{c}\text { STANDAR } \\
\text { APCC }\end{array}$ \\
\hline $\begin{array}{l}\text { Asam } \\
\text { laurat } \\
\text { (C12) }\end{array}$ & MCFA & 39,0 & $45,1-53,2$ & $43-53$ \\
\hline $\begin{array}{l}\text { Asam } \\
\text { miristat } \\
\text { (C14) }\end{array}$ & MCFA & 17,8 & $16,8-21$ & $16-21$ \\
\hline $\begin{array}{l}\text { Asam } \\
\text { palmitat } \\
\text { (C16) }\end{array}$ & LCFA & 8,7 & $7,5-10,2$ & $7,5-10$ \\
\hline
\end{tabular}

Dengan demikian kadar SCFA dan MCFA yang tinggi akan menaikkan kualitas terutama yang berkaitan dengan sumber energi dan vitalitas tubuh. Sebagian besar asam lemak yang terkandung di dalam VCO produk Kelompok Tani Bina Warga 1 Desa Pancanegara, Kecamatan Pabuaran adalah dari jenis asam lemak jenuh rantai pendek dan sedang (MCFA). Maka pantaslah kalau VCO memiliki banyak manfaat terutama yang berkaitan dengan kesehatan tubuh.

\section{Analisis Standar Keawetan VCO.}

Analisis standar keawetan VCO produk Kelompok Tani Bina Warga 1 Desa Pancanegara, Kecamatan Pabuaran dilakukan berdasarkan hasil pengukuran dan pengujian terhadap beberapa parameter yang berkaitan dengan penyebab kerusakan VCO yaitu adanya asam lemak bebas dan air.

\section{Analisis kadar asam lemak bebas}

Penentuan kadar asam lemak bebas berkaitan dengan kandungan asam lemak bebas yang terdapat di dalam VCO.Hasil analisis menunjukkan bahwa asam lemak bebas di dalam VCO produk Kelompok Tani Bina Warga 1 Desa Pancanegara yang dibuat dengan cara pemancingan mempunyai kadar 0,10 \%. Hal itu bisa terjadi karena selama proses tidak terjadi reaksi hidrolisis lemak menjadi asam-asam lemak bebas dan gliserol ataupun aktivitas enzimatis dan mikroorganisme. Adanya asam lemak bebas di dalam VCO bisa menurunkan kualitasnya.
Berdasarkan standar kualitas APCC kandungan asam lemak bebas di dalam VCO tidak boleh lebih dari $0,2 \%$.

\section{Analisis kadar air.}

Hasil pengukuran menunjukkan bahwa kadar air di dalam VCO produk Kelompok Tani Bina Warga 1 Desa Pancanegara yang sangat kecil sekali $(0,19$ \%). Hal itu disebabkan karena waktu pemisahan yang cukup lama sehingga hanya sedikit air yang masih tersisa. Agar kualitas VCO dapat dipertahankan maka sebaiknya kadar air harus benar-benar hilang dari VCO. Adanya air akan menyebabkan terjadinya reaksi reduksi-oksidasi (redoks), enzimatis maupun mikroorganisme yang akhirnya akan merusak VCO.

\section{SIMPULAN}

Proses identifikasi senyawa kimia yang dilakukan terhadap VCO produk Kelompok Tani Bina Warga 1 Desa Pancanegara, Kecamatan Pabuaran menghasilkan informasi sebagai berikut:

Pada proses pembuat VCO dengan cara penambahan natrium karbonat diperoleh kandungan VCO sebesar 0,130 liter/kg kelapa. Hasil analisis kualitas fisik yaitu tetap jernih, tetap gurih/enak dan tetap wangi dengan berat jenis VCO sebesar 0,925 (g/ml) (APCC sebesar 0,915-0,920 (g/ml).

\section{SARAN}

Berhubung karena sangat singkatnya waktu penelitian maka hasil dari penelitian ini perlu dievaluasi kembali . Banyak hal kendala yang ditemukan didalam percobaan ini sehingga banyak hal yang tidak dilakukan dengan sempurna. Untuk itu perlu ada kajian lebih lanjut tentang metoda ini. Disarankan minyak VCO yang dihasilkan digunakan untuk kepentingan industri.

\section{DAFTAR PUSTAKA}

Arie Febriyanto Mulyadi,2011,” Perancangan unit pengolahan virgin coconut oil (VCO) skala industry kecil: kajian lokasi tanam dan lama waktu tunda kelapa sebelum proses", Universitas Brawijaya, Malang.

I Wayan Karta, Ni Made Ary Sarasmita,2013, "Analisis Virgin Coconut Oil (VCO) dan pengembangan diversivikasi produknya pada KWT Balicocos Desa Tengkudak Kabupaten Tabanan”, Universitas Pendidikan Ganesha, Singaraja

Muhammad Asyari, B. Cahyono,2006," Prastandarisasi: Produksi dan analisis minyak virgin coconut oil (VCO)”, Universitas Diponegoro, Semarang. 
Nur Hapsari, Tjatur Welasih,2010,” Pembuatan virgin coconut oil (VCO) dengan metode sentrifugasi”, UPN.Veteran Jawa Timur, Surabaya.

Vigna Dyah Puspitasari,2010,” Kadar asam laurat dan fenol virgin coconut oil (VCO) yang diolah dengan metode pemanasan, sentrifugasi dan pancingan", Universitas Diponegoro, Semarang

Wawan e. Efendi,2009,” Revitalisasi minyak kelapa murni (VCO) dalam dunia gizi dan kesehatan", Academia.edu. 